\title{
O SENTIDO DEMOCRÁTICO E CORPORATIVO DA NÃO-CONSTITUIÇÃO DE 1937
}

\author{
The democratic and corporative meaning \\ of the non-Constitution of 1937
}

LUCIANO ARONNE DE ABREU

http://dx.doi.org/10.1590/S2178-14942016000200008

Luciano Aronne de Abreu é mestre em História do Brasil pela PUC-Rio Grande do Sul (1995) e doutor em Estudos Históricos Latino-Americanos pela Universidade do Vale do Rio dos Sinos (2005). Atualmente é professor do Programa de Pós-Graduação em História da PUC-RS (luciano.abreu@pucrs.br).

Artigo recebido em 17 de dezembro de 2015 e aprovado para publicação em 15 de junho de 2016. 


\title{
RESUMO
}

Ainda hoje, há uma carência de estudos a respeito da Constituição de 1937, talvez devido a um comum desprezo de juristas e historiadores por esse documento. De um lado, porém, entende-se que ele teria representado uma síntese das principais ideias jurídicas e políticas defendidas por intelectuais como Oliveira Viana e Francisco Campos; de outro lado, teria também representado um momento de institucionalização e legitimação de um regime forte. Diante desse quadro, tem-se aqui por objetivo analisar o possível sentido de legitimidade jurídica e política da Constituição de 1937 e seu caráter democrático e corporativo, de acordo com seus próprios termos e com a definição dos intelectuais acima referidos.

Palavras-Chave: Constituição de 1937; Estado Novo; Oliveira Viana; Francisco Campos; democracia; corporativismo.

\begin{abstract}
Even to this day there is a lack of studies concerning the Brazilian Constitution of 1937, perhaps due to a common disdain of jurists and historians for this document. On one hand, it is understood that it would have represented a summary of the main legal and political ideas advocated by intellectuals like Oliveira Viana and Francisco Campos; on the other hand, it would have also represented a moment of institutionalization and legitimation of a strong regime. We intend to analyze here the possible sense of legal and political legitimacy of the 1937 Constitution and its democratic and corporate character in accordance with its own terms and with the definition of the intellectuals mentioned above.
\end{abstract}

Keywords: Constitution of 1937; the "Estado Novo" dictatorship; Oliveira Viana; Francisco Campos; democracy; corporatism.

\section{RÉSUMÉ}

Encore aujourd'hui il n'y a pas assez d'études sur la Constitution brésilienne de 1937, peut-être parce que juristes et historiens méprisent ce document. D'une part, ils pensent que cette Constitution n'est qu'une synthèse des principales idées juridiques et politiques défendues par des intellectuels tels qu'Oliveira Vianna et Francisco Campos. D'autre part, on la voit aussi comme un moment d'institutionalisation et de légitimation d'un régime politique fort. Cet article cherche à faire une analyse du sens possible de légitimité juridique et politique de la Constitution de 1937 et de sa nature démocratique et corporative, selon ses propres termes et la définition des intelectuels cités.

Mots-ClÉs: Constitution de 1937; la dictature de I'"Estado Novo"; Oliveira Viana; Francisco Campos; démocratie; corporatisme. 
"Não há hoje um povo que não clame por um César"

(Francisco Campos, Conferência na Escola Nacional de Belas Artes, 28/09/1935)

inda hoje, cerca de 80 anos depois de sua outorga, são raros e limitados os estudos es-
pecíficos de juristas e historiadores sobre a Constituição de 1937. Talvez essa carência de estudos se deva a um comum desprezo por esse documento, por seu caráter de outorga e suposta falta de legitimidade jurídica e política. Para uns e outros, sejam eles contemporâneos ou não à Constituição, sua falta de legitimidade jurídica e política não apenas justificaria o desprezo por esse documento como também demonstraria seu caráter limitado como fonte para a compreensão do Estado Novo de Vargas e seu modelo político autoritário e corporativo. Nas palavras de Walter Costa Porto (2001: 14), o grande obstáculo "para o exame da Constituição de 10 de novembro de 1937 é exatamente essa 'falta de respeito' que lhe devota o meio político e, afinal, a falta de isenção dos analistas, raros, de seu conteúdo".

Em contraponto a essa visão, entende-se aqui que a Constituição de 1937 representou, de um lado, uma síntese das principais ideias jurídicas e políticas defendidas por importantes intelectuais conservadores da chamada "geração dos anos 1920-40" (Pécaut, 1989), tais como Oliveira Viana e seu próprio autor, Francisco Campos; de outro lado, ainda que ela própria jamais fosse institucionalizada e efetivamente aplicada do ponto de vista jurídico, a Constituição de 1937 representou também um importante momento de institucionalização política do Estado Novo. Nesse sentido, este estudo tem por objetivo analisar o caráter supostamente democrático e corporativo atribuído pelos intelectuais e juristas acima referidos ao Estado Novo e à sua Constituição e, em contraponto, enfatizar o caráter de exceção desse regime e definir a Carta de 1937 como uma não-Constituição, dada sua falta de institucionalidade jurídica.

\section{A CONSTITUIÇÃO E SEUS FUNDAMENTOS INTELECTUAIS}

o longo da Primeira República (1889-1930) havia uma forte preocupação nos meios
políticos e intelectuais brasileiros em encontrar as origens de nosso atraso e em apontar alternativas para sua superação. Assim, a chamada geração dos anos 1920-40 se 
mostraria muito disposta a auxiliar o Estado na construção de uma nova sociedade em bases racionais, supostamente científicas e adequadas à realidade nacional, ao mesmo tempo em que mantinha "uma linguagem que é a do poder" e proclamava, "em alto e bom som, a sua vocação para elite dirigente" (Pécaut, 1989: 22). Dessa geração, pode-se dizer que Oliveira Viana e Francisco Campos seriam dois dos mais importantes representantes, tanto por suas produções intelectuais como pelos altos cargos que ocupariam durante o Estado Novo, respectivamente de consultor jurídico do Ministério do Trabalho (1932-40) e ministro da Justiça (1937-43).

Na opinião de Oliveira Viana, que procurou dar um caráter científico aos seus estudos histórico-sociológicos sobre a formação do Brasil e a raiz dos seus problemas, a dispersão dos latifúndios e o insolidarismo social seriam heranças coloniais ainda hoje presentes em nossa sociedade, disso resultando o fraco desenvolvimento no país da indústria, do comércio e das corporações urbanas; ou seja, "na amplíssima área de latifúndios, só os grandes senhorios rurais existem. São os grandes domínios como que focos solares: vilas, indústrias, comércio, tudo se ofusca diante da sua claridade poderosa" (Viana, 1920: 130). Em tais condições, considerando ainda a chamada "anarquia branca", ou seja, a ausência do Estado e sua incapacidade de amparar os "cidadãos sem fortuna", Oliveira Viana diz que a estes restava somente se concentrar em torno dos senhores rurais: "o que impele a nossa população inferior dos campos a congregar-se sob os senhores territoriais é a necessidade de defesa contra a anarquia branca, dominando, de alto a baixo, desde os primeiros séculos, toda a sociedade rural" (Viana, 1920: 150). 0 espírito de clã, portanto, constituiria a base de nossa organização social, sendo os clãs fazendeiros a única forma de solidariedade que 0 povo conseguiu formar e organizar em quatro séculos de história - afinal "nenhuma classe podia voltar-se contra os senhores de terra, porque todas elas, pela ação simplificadora do grande domínio, são atraídas para a aristocracia rural e se deixam absorver por ela" (Viana, 1920: 172). Além disso, não apenas a nobreza fazendeira não teria sofrido nenhuma "pressão tirânica" do poder, como este também teria no Brasil uma expansão muito menor que a da colonização. Ainda segundo Oliveira Viana, "o poder público tem uma marcha mais remorada do que a massa social, cujos movimentos incumbem a ele regular e dirigir. Há uma visibilíssima discordância, ainda hoje sensível, entre a área demográfica e a área política, entre a área da população e o campo de eficiência da autoridade pública" (Viana, 1920: 210). Ou seja, diria o autor, de uma sociedade ganglionar resultaria um poder político também ganglionar.

Nos tempos coloniais, nossos estadistas teriam então se resignado e acomodado a essa fatalidade do meio geográfico. Proclamada a independência, porém, superar tal 
dispersão social e política, que fazia do Brasil "um amontoado de quase vinte capitanias dispersas" (Viana, 1923: 213), seria condição para a manutenção da sua unidade política e para a construção da nação. Para tanto, os estadistas do Império teriam encontrado "à mão, por um acaso feliz" , na opinião de Oliveira Viana, a figura central do rei, peça essencial para a unificação do poder. Além disso, teriam contado também com sua ação moderadora sobre todos os órgãos do mecanismo político - o Poder Moderador, cujos poderes excepcionais seriam muito bem sintetizados pela máxima do Visconde de Itaboraí de que no Brasil "o rei reina, governa e administra" (Viana, 1923: 230). Com o advento da República, ao contrário, sem mais a ação pessoal do rei, Oliveira Viana diz que "os fatores geográficos reivindicam os seus direitos e o regime federativo surge como o meio de evitar a secessão" (Viana, 1923: 222).

Na opinião do autor, portanto, os limites impostos pela Constituição de 1891 ao poder central e a ausência de um líder forte e moderador do jogo político seriam os principais problemas da República no Brasil, cujo modelo democrático-liberal seria inadequado à realidade nacional, mero idealismo utópico baseado em fórmulas estrangeiras. Nesse sentido, diz ele: "Veio a República. Veio a Democracia. Veio a federação. E para logo se levantou um sussurro de desapontamento do seio da turba fanatizada - e esse desapontamento se acentuou, com o tempo, numa permanente desilusão" (Viana, 1923: 28-29).

A superação desses problemas, no entanto, dado que o espírito de clã se constituiria na base de nossa organização social, seria algo muito mais complexo do que simplesmente realizar uma reforma constitucional ou política no país. Ao contrário disso, as reformas constitucionais seriam para Oliveira Viana apenas meios auxiliares de outras reformas maiores, "de caráter social e econômico, que devemos realizar, se quisermos estabelecer aqui o 'regime democrático', o 'regime de opinião', o 'regime do governo do povo pelo povo'" (Viana, 1923: 64). Em sua definição, a "democracia é o governo da opinião", cuja organização e manifestação poderia se dar mesmo sem a existência de partidos políticos, de eleições ou do voto, o qual não seria nada além de uma forma de expressar a opinião do povo, não necessariamente a única e nem sempre a melhor, podendo a democracia se organizar mesmo sem eleições ou eleitores: "Eleições e eleitores não são coisas principais numa democracia; são meios para atingir o fim - e não são nem o meio único, nem o melhor dos meios. 0 que é principal numa democracia é a existência de uma opinião organizada" (Viana, 1923: 90).

Nesses termos, o autor diria que o sentido nacional da revisão no Brasil iria muito além de uma nova constituição. Ele o resumiria na seguinte fórmula: "organização sólida e estável da liberdade, principalmente da liberdade civil, por meio de uma organização sólida e 
estável da autoridade, principalmente da autoridade federal" . Quanto à autoridade, destacava especialmente os Poderes Executivo e Judiciário: "O Poder Legislativo (na sua modalidade parlamentar) é, ao contrário do que parece, de importância secundária. Um Poder Executivo forte; ao lado dele e contra ele, um Poder Judiciário ainda mais forte - eis a fórmula" (Viana, 1930: 62). Em sua opinião, portanto, seria perfeitamente possível um governo de liberdade civil sem liberdade política, mas não o contrário, sendo o governo do "bom tirano" sua maior prova. Assim, a verdadeira democracia não seria baseada na liberdade individual, na participação política do indivíduo, e sim na opinião organizada das classes econômicas e na sua participação nos negócios públicos, de acordo com um modelo corporativo: "Uma democracia só é realmente digna deste nome quando repousa, não só na atividade dos seus cidadãos, agindo como tais, isto é, como indivíduos; mas na atividade dos seus cidadãos agindo como membro desta ou daquela corporação, como parcelas de um agrupamento, unidos pela consciência de um interesse comum, de classe" (Viana, 1930: 119-120).

Estas mesmas ideias seriam partilhadas por Francisco Campos, ainda que este se baseasse apenas na observação da realidade do seu tempo, sem recorrer aos argumentos histórico-sociológicos de Oliveira Viana. Por premissa, tal como Oliveira Viana, Francisco Campos também afirmaria a inadequação do que chamou de "teologia liberal" e a necessidade de se construir no Brasil um novo regime de opinião que prescindisse de partidos políticos, de eleições e do voto.

Segundo ele, vivia-se naquele tempo uma época de transição, "em que o passado continua a interpretar o presente; em que o presente ainda não encontrou as suas formas espirituais, e as formas espirituais do passado, com que continuamos a vestir a imagem do mundo, se revelam inadequadas, obsoletas ou desconformes" (Campos, 1940: 5). A esse respeito, Francisco Campos diria ainda que as épocas de transição são trágicas, pois tornam agudos os conflitos "entre as formas tradicionais do nosso espírito, aquelas em que fomos educados e de cujo ângulo tomamos a nossa perspectiva sobre o mundo, e as formas inéditas sob as quais os acontecimentos apresentam a sua configuração desconcertante" (Campos, 1940: 5). No mundo moderno, portanto, todas as soluções que até então "constituíam nossa herança intelectual, política e moral" se transformaram em problemas, devendo a educação ser "uma educação para problemas, e não para soluções, não para este ou aquele regime de vida, pois não se sabe ou não se acredita saber em que quadro de linhas móveis e flutuantes irá o homem viver". Assim, questiona o autor, "como educar para a democracia se esta não é hoje senão uma Cafarnaum de problemas, muitos dos quais propondo questões cuja solução provável implicará o abandono dos seus valores básicos ou fundamentais?" (Campos, 1940: 6). 
Em sua opinião, a sociedade do seu tempo era marcada pelo advento das massas e por sua entrada no mundo político, levando à irracionalidade da vida política e ao consequente divórcio entre democracia e liberalismo. Nesse sentido, diz ele, a integração total das massas em regime de Estado irá se dar somente pelo apelo "às forças irracionais ou às formas elementares da solidariedade humana", sendo o Estado não mais do que "a projeção simbólica da unidade da nação" . Assim, quanto maiores as massas a serem politicamente integradas, maiores deverão ser os instrumentos espirituais dessa integração, que é uma integração total: "A política transforma-se dessa maneira em teologia. Não há formas relativas de integração política, e o homem pertence, alma e corpo, à nação, ao Estado, ao partido. As categorias da personalidade e da liberdade são apenas ilusões do espírito humano" (Campos, 1940: 12-13). Nesse sentido, como centro de integração política dessa nova sociedade, o autor destaca o fascínio das massas pela personalidade carismática: "quanto mais volumosas e ativas as massas, tanto mais a integração política só se torna possível mediante o ditado de uma vontade pessoal. 0 regime político das massas é o da ditadura", sendo sua única forma de expressão por meio do plebiscito ou do voto-aclamação, "não o voto democrático, expressão relativista e cética de preferência de simpatia, do pode ser que sim pode ser que não, mas a forma unívoca, que não admite alternativas, e que traduz a atitude da vontade mobilizada para a guerra" (Campos, 1940: 16).

Nesses termos, o já citado divórcio entre democracia e liberalismo se daria justamente porque a democracia liberal supunha que "as decisões políticas são obtidas mediante processos racionais de deliberação" e que a dialética política seria um estado de tensão puramente ideológica, "capaz de resolver-se num encontro de ideias, como se se tratasse de uma pugna forense" (Campos, 1940: 17), enquanto o clima das massas seria o das grandes tensões políticas que não se deixam resolver em termos intelectuais ou por meio de polêmicas de ideias, ou seja, seu processo dialético não seria adequado às regras do jogo parlamentar ou às premissas racionalistas do liberalismo.

Ao se referir aos partidos políticos e ao parlamento, por exemplo, Francisco Campos diria que os primeiros não tinham qualquer conteúdo programático e que "entre esses quadros partidários e o sentimento e a opinião do país não existia a menor correspondência" (Campos, 1940: 38); quanto ao parlamento, "é o lugar onde nada acontece e nada se decide" (Campos, 1940: 29). Ou seja, considerando a legislação uma das funções essenciais do governo, o alto custo da máquina parlamentar e sua baixa produção, Francisco Campos dizia que "esta deveria ser substituída por outro processo ou mecanismo mais adequado de legislação" (Campos, 1940: 43). Em outras palavras, a democracia perdia para ele o seu caráter relativista associado à doutrina liberal e adquiria um sentido monista de integração política "em que as decisões fundamentais são abertamente subtraídas ao processo 
dialético de discussão, da propaganda e da publicidade, para serem imputadas a um centro de vontade, de natureza tão irracional como os centros de decisão política dos regimes de ditadura" (Campos, 1940: 21-22).

Em sua opinião, como em Oliveira Viana, essa nova democracia teria também um sentido corporativo, devendo as associações profissionais participar dos conselhos de governo por um processo adequado, "em que possam exercer a sua influência segundo a atmosfera, os métodos, os instrumentos próprios da sua natureza, do seu espírito e do seu ângulo visual, a fim de que as decisões que interessam à economia nacional provenham de algum centro de vontade qualificado para isso (...)" (Campos, 1940: 46). Dizia ainda que esta nova democracia, ao contrário do seu conceito negativo do século XIX, que impunha limites à atuação do Estado, tinha um sentido positivo, de assegurar aos homens o gozo de novos direitos, devendo 0 Estado ser forte o suficiente para garantir sua efetividade, exercendo "de modo efetivo o controle de todas as atividades sociais - a economia, a política, a educação" (Campos, 1940: 56).

Em face destas concepções, pode-se afirmar o pouco apreço de Oliveira Viana e Francisco Campos pelas normas instituídas pela Constituição de 1937, que, embora tenha marcado a institucionalização política do Estado Novo, não seria ela própria institucionalizada durante todo o seu período de vigência. Para o primeiro, mais importante que a Constituição seria a organização sólida e estável da liberdade civil e da autoridade do poder central; para o segundo, acima da constituição escrita haveria "uma constituição não escrita, na qual se contém a regra fundamental de que os direitos de liberdade são concedidos sob a reserva de se não envolverem no seu exercício os dogmas básicos ou as decisões constitucionais relativas à substância do regime" (Campos, 1940: 21).

Assim, embora a própria Constituição previsse sua legitimação por meio de um plebiscito (art. 187), esses intelectuais entendiam que o poder constituinte do novo regime não seria dado pela participação direta e individual do povo, mas pela integração política das massas ao Estado, em nome da nação e dos seus interesses coletivos. Porém, como bem definiram os professores da Faculdade Nacional de Direito, a Constituição de 1937 acabou por se constituir apenas numa norma de fato, carente de legitimidade jurídica e política, "a que não resta outra existência senão a da força que a mantém". ${ }^{\prime}$

\section{Os FUNDAMENTOS DE UMA NOVA DEMOCRACIA CORPORATIVA}

pesar de sua falta de legitimidade, pode-se afirmar que a Constituição de 1937 contri-
buiria para o processo de institucionalização e legitimação política do Estado Novo no Brasil, justificando desde o seu preâmbulo a necessidade de se introduzir no país um governo 
forte e nacionalista como uma resposta às "legítimas aspirações do povo brasileiro" e ao "estado de apreensão criado no país pela infiltração comunista". Em igual sentido, dada a gravidade da situação, a própria Constituição, em suas Disposições Transitórias e Finais, decretaria em todo o país o estado de emergência (art. 186), ao invés de apenas autorizar o presidente a fazê-lo, como nas constituições anteriores de 1891 e de 1934.

Nesses termos, o regime justificava que a concentração de poderes do presidente não seria mero ato arbitrário de Getúlio Vargas, mas sua legítima obrigação constitucional, dada a crise então vivida pelo país e a incapacidade das instituições anteriores de assegurarem sua estabilidade e segurança. Assim, ao longo de suas 26 partes e 187 artigos, $^{2}$ a Constituição definiria com precisão as novas atribuições do presidente, de modo a introduzir no país um regime de concentração de poderes, como definiam seus intérpretes, em lugar da tradicional democracia de partidos e da divisão de poderes então vigente.

A esse respeito, dizia Oliveira Viana que o que o Brasil precisa não é de um partido único, como nos casos de Alemanha e Itália, e sim de um presidente único, ou seja, "do Presidente que não divida com ninguém a sua autoridade; do Presidente em quem ninguém mande; do Presidente soberano, exercendo, em suma, o seu poder em nome da nação, só a ela subordinado e só dela dependente" (Viana, 1939: 207). Em sua opinião, portanto, o ideal de um presidente armado dos poderes excepcionais previstos pela Constituição de 1937 não seria o de um chefe de partido, e sim o de uma autoridade que se colocasse acima dos partidos e grupos de qualquer natureza, "de modo a poder dirigir a nação do alto, num sentido totalitário, agindo como uma força de agregação e unificação - e não como uma força de desagregação e de luta" (Viana, 1939: 208). Francisco Campos, por sua vez, em entrevista ao Jornal do Comércio (1938), diria que a divisão de poderes não obedece a uma lei eterna, mas a "influências de ordem contingente e histórica. 0 Parlamento não tem um direito natural à legislação. Ele legisla na medida das suas forças e da sua competência". Segundo ele, "a mecânica política não é a mecânica de Newton. A massa dos poderes gravita para os órgãos do governo segundo razões de conveniência, de utilidade e de adequação", ou seja, "cada época tem a sua divisão de poderes, e a lei do poder é, em política, a da capacidade para exercê-lo" (Campos, 1938: 31-32). Naquele contexto, diria ainda Francisco Campos, a legislação perdera o seu caráter exclusivamente político e passara a ter um caráter eminentemente técnico, sendo de competência do Parlamento a "política legislativa" e do Executivo a "técnica legislativa", o que justificaria, portanto, a concentração de poderes e as atribuições legislativas que a Constituição de 1937 conferira ao presidente.

Araújo Castro e Pontes de Miranda, por sua vez, sem negar a concentração de poderes do Executivo e os argumentos acima citados de Oliveira Viana e Francisco Campos, se 
propõem analisar a Constituição de 1937 em termos jurídicos, embora não exclusivamente. Para o primeiro, autor da obra A Constituição de 1937, não se deve concluir pela inexistência da divisão de poderes no novo regime, pois esta "existe sempre que cada um dos poderes pode agir dentro da esfera de ação traçada pela Constituição". Ou seja, admitindo não haver uma lei eterna para a divisão de poderes e considerando, ao contrário, haver definições específicas na Constituição para o Poder Legislativo, dividido em Câmara dos Deputados e Conselho Federal, o presidente da República e a Justiça, Araújo Castro diria que nela "estão delimitadas precisamente as atribuições do Judiciário e as atribuições e prerrogativas do Presidente da República". Desta maneira, diz ele, "nunca poderá haver confusão de funções, agindo cada poder na órbita de suas atribuições, e é isso, repetimos, o que constitui a principal característica da divisão de poderes" (Castro, 1941: 52-53). Para Pontes de Miranda, não há dúvida de que o legislador constituinte de 1937 riscou do seu texto o preceito da separação e independência dos poderes, além de atribuir ao Executivo a feitura das leis com o nome de decretos-lei. Por outro lado, o autor observa que a guarda da Constituição caberia, segundo seus próprios termos, aos três poderes: "ao Poder Judiciário, na apreciação do caso concreto; ao Presidente da República, a cujo juízo se deixa o submeter, ou não, o julgamento da lei ao reexame parlamentar; finalmente, ao Poder Legislativo, que, por dois terços de votos, se pode manifestar contra a declaração de inconstitucionalidade" (Pontes de Miranda, 1938: 24-25).

De todo modo, segundo levantamento de Augusto Estellita Lins, pelo menos 50 dos 187 artigos da Constituição de 1937 tinham por objetivo justamente o fortalecimento do presidente da República e a concentração de poderes, ${ }^{3}$ porque, afinal, nela "só se cogita de um poder: o poder político que emana do povo; e só se fala nos Poderes Executivo, Legislativo e Judiciário como órgãos daquele poder único. (...) Não existe o problema da divisão dos poderes nem o dos seus limites constitucionais" (Lins, 1938: 100-101).

Dito isto, ainda que não se tenha a pretensão de analisar um a um os 50 artigos apontados por Estellita Lins, devem-se citar alguns exemplos do modelo político de concentração de poderes proposto pela Constituição de 1937, segundo seus próprios termos e definições. Em primeiro lugar, tal como já referido em relação ao seu art. 186, que decretara o estado de emergência em todo o país, seria também a própria Constituição, em seus artigos 178 e 180, que decretaria a dissolução dos órgãos legislativos em seus diferentes níveis e atribuiria ao presidente da República o poder de expedir decretos-leis. Além disso, o art. 178 diria também que "as eleições do Parlamento Nacional serão marcadas pelo Presidente da República, depois de realizado o plebiscito a que se refere o art. 187". Tal plebiscito, a que a própria Constituição deveria ser submetida, seria por sua vez realizado "na forma regulada em decreto 
do Presidente da República" (art. 187). Mais uma vez, portanto, os termos da Constituição reafirmam que tal concentração de poderes - fechar os órgãos legislativos e expedir decretos - não seria mero ato arbitrário do presidente, mas sua legítima obrigação constitucional. De forma inversa ao usual, a Constituição autorizaria o presidente a abrir o Parlamento quando julgasse adequado e conveniente, e não a fechá-lo devido à gravidade da situação do país e seu estado de emergência.

Por outro lado, mais do que legitimar os seus poderes, a Constituição de 1937 colocaria o presidente da República e suas prerrogativas acima dela própria, como se pode inferir dos termos do seu art. 73: "O Presidente da República, autoridade suprema do Estado, coordena a atividade dos órgãos representativos, de grau superior, dirige a política interna e externa, promove e orienta a política legislativa de interesse nacional, e superintende a administração do país" (Constituição de 1937, art. 73). Mais adiante, referindo-se aos estados de emergência ou de guerra, como então se vivia, a Constituição diz que durante sua vigência os "atos praticados [pelo Presidente] em virtude deles não poderão conhecer os juízes e tribunais" (art. 170). Diz ainda que nesse período "deixará de vigorar a Constituição nas partes indicadas pelo Presidente da República" (art. 171). Na prática, portanto, como teria ocorrido durante todo o Estado Novo, esse último artigo permitiria ao presidente alterar ou mesmo ignorar completamente a Constituição, sem limites ao seu poder. Naquele contexto, em sua obra A Constituição de dez de novembro explicada ao povo, Antônio Figueira de Almeida dizia que "sem essa medida o governo poderia ficar desarmado para a realização dos atos necessários para a defesa da ordem pública" (Almeida, 1940: 131). Em termos jurídicos, Pontes de Miranda justificaria tal condição do presidente porque o seu poder não seria advindo da Constituição de 1934, mas de uma nova ordem de coisas por ele próprio instituída. Em suas palavras, diz ele, o ato de outorga da Constituição "foi concebido como ato do Presidente da República dos Estados Unidos do Brasil, mas o Presidente da República, que assim procedia, já exercia o cargo em nome de uma nova ordem de coisas, e não por força da Constituição de 1934, de que lhe adviera, até então, o poder" (Pontes de Miranda, 1938: 180).

Outros exemplos do modelo de concentração de poderes da Constituição de 1937 seriam aqueles previstos no seu art. 9ำ que atribui ao Governo Federal o direito de intervir nos Estados "mediante a nomeação, pelo Presidente da República, de um Interventor"; no art. 75, que diz ser prerrogativa do presidente, quando de sua sucessão, "indicar um dos candidatos à Presidência da República" (letra a); e no art. 167, sobre a responsabilidade do presidente após o fim dos estados de emergência ou de guerra. Nesse caso, embora o caput do artigo determine ao presidente comunicar "à Câmara dos Deputados as medidas tomadas durante o período de vigência de um ou de outro", o parágrafo único garante ao presidente, em caso 
de não aprovação de suas medidas, "o direito de apelar da deliberação da Câmara para o pronunciamento do país, mediante a dissolução da mesma e a realização de novas eleições".

Em síntese, tais evidências de concentração de poderes configurariam no Brasil um regime de presidente único, como dizia Oliveira Viana, ou seja, não subordinado ao Parlamento nem a ninguém, mas exercendo o seu poder em nome da nação, só a ela subordinado e só dela dependente. Porém, apesar dos esforços dos intelectuais e juristas acima citados para legitimar a Constituição de 1937 e sua concentração de poderes como juridicamente válidas e adequadas à realidade nacional, é evidente que uma Constituição que supõe haver um poder superior a ela - o do presidente da República, só pode ser definida como uma não-Constituição, por não emanar, como define a teoria constitucional, de um poder constituinte, e sim do arbítrio de um regime de exceção.

Apesar disso, seus ideólogos e intérpretes se esforçam ainda em argumentar que o Estado Novo e sua Constituição seriam profundamente democráticos, não no sentido liberal, dada sua inadequação à realidade brasileira, mas no de uma nova democracia autoritária e corporativa.

A esse respeito, de forma irônica, Oliveira Viana diria que, para os políticos e publicistas liberais, tudo numa democracia se resume ao voto: "são votômanos, votólatras e votóparos. Todas as vezes que pensam no problema da democracia, a primeira ideia que Ihes acode é o voto (e parece que não lhes acode mais nada)". Entretanto, conclui ele, não se lembram de gritar "a palavra justa, a palavra verdadeira, aquilo que devia ser gritado aos quatro cantos do país: organizemos a opinião! Porque isto é que é o essencial. Democracia é o governo da opinião" (Viana, 1939: 230). Assim, afastada a intervenção dos partidos e do voto, caberia ao Estado autoritário buscar nas classes organizadas suas novas fontes de opinião e de democracia. Seria, então, através das suas associações profissionais, instituições sociais e corporações de cultura que o governo poderia se informar "dos diversos interesses coletivos, que devem ser, ou vigiados, ou defendidos, ou atendidos pelo Estado; nelas, portanto, numa democracia sem partidos, as fontes legítimas da opinião democrática" (Viana, 1939: 213). Essa nova democracia de tipo corporativo, como Oliveira Viana definiria o Estado Novo, teria por fundamento a própria estrutura das sociedades modernas, ou seja, "o advento das grandes indústrias, os modernos processos de negócio, as grandes concentrações comerciais, a crescente industrialização do trabalho agrícola, etc." (Viana, 1939: 242). Segundo ele, o verdadeiro caminho da democracia não seria eleger deputados, mas desenvolver os conselhos técnicos e as organizações de classe. ${ }^{4}$ Em suas palavras, "0 sentido da Constituição de 37 é, pois, o da democracia social ou, melhor, da democracia corporativa (...)" (Viana, 1939: 215-216). 
Sobre essas mesmas questões, Francisco Campos diria que os partidos políticos são meros falsificadores da opinião pública, não seus representantes: "Eles se haviam transformado em meros instrumentos de falsificação das decisões populares, ou em simples cobertura para a ação pessoal de chefes locais ambiciosos de influência no governo da nação" (Campos, 1937: 8). Em sua opinião, a democracia de partidos havia se transformado numa "guerra civil organizada e codificada" (Campos, 1937: 9-10). Em seu lugar, portanto, que Francisco Campos diria ser obsoleto, o autor se declara a favor de uma nova ordem racional baseada no predomínio dos interesses coletivos sobre os individuais - um regime corporativo, o qual não excluiria a liberdade, mas tornaria mais justo o seu exercício. Aí residiria a verdadeira justiça e a democracia, cabendo ao Presidente, chefe responsável da nação, "apelar frequentemente para a opinião", tendo assim "o seu mandato um caráter eminentemente democrático e popular" (Campos, 1937: 41). Em entrevista ao Jornal do Comércio, contudo, o então Ministro da Justiça esclareceria que afirmar que o Estado é produzido pela vontade popular "não implica a conclusão de que o sufrágio universal seja um sistema necessário de escolha, nem a de que o Presidente da República deva exercer o seu cargo por um curto período de tempo, não podendo ser reeleito" (Campos, 1938: 9). Segundo ele, seria preciso não confundir a máquina democrática com o ideal democrático; ao contrário, para reivindicar o ideal democrático seria necessário justamente quebrar a máquina democrática. Assim, diz ele, "é desnecessário insistir que o Estado brasileiro, sendo democrático, é também autoritário, cabendo ao Presidente da República a autoridade suprema do Estado, exercida em nome do povo e no interesse do seu bem estar, de sua honra, da sua independência e da sua prosperidade" (Campos, 1938: 16-17).

Em tal perspectiva, pode-se dizer que o caráter democrático da Constituição de 1937 residiria, essencialmente, em seus variados apelos à opinião popular, por meio de plebiscitos, e em sua defesa dos interesses coletivos, por meio das corporações.

Essa seria também a opinião de juristas como Pontes de Miranda que, em sua obra Comentários à Constituição Federal de 10 de novembro de 1937, procura destacar o caráter essencialmente jurídico de sua interpretação, que se ateria ao que "ela [a constituição] diz, e não ao que a respeito dela foi dito, menos ainda o que se pensou e disse que significaria" (Pontes de Miranda, 1938: 9). Nesse sentido, diz o autor, interpretar é fazer viver, o que não se faz com simpatia ou antipatia: "com a antipatia não se interpreta - ataca-se; porque interpretar é pôr-se do lado do que se interpreta, numa intimidade maior do que permite qualquer anteposição, qualquer contraste, por mais consentinte, mais simpático que seja, do intérprete e do texto. Portanto, a própria simpatia não basta". Ao contrário, seria "preciso compenetrar-se do pensamento que esponta nos preceitos jurídicos (...)", tal como ele mesmo teria empreendido 
no seu trabalho, um estudo de caráter "lógico e técnico da terceira Carta Republicana do Brasil" (Pontes de Miranda, 1938: 13). Assim, diz Pontes de Miranda, 0 art. 174, § 4으 da Constituição de 1937 não excluiu a democracia do Brasil, "a despeito da acentuação simétrica do centro, com que se deu ao Poder Executivo, ou, mais precisamente, ao Presidente da República, uma soma enorme de ingerência e de decisão, na vida do país" (Pontes de Miranda, 1938: 15). Isso porque, segundo ele, o seu art. 10 assegura que "o poder político emana do povo e é exercido em nome dele, e no interesse do seu bem estar, da sua honra, da sua independência e da sua prosperidade" (Constituição de 1937, art. 1ํ). Além disso, observando que seria um anacronismo no século XX uma constituição não se preocupar com a questão social, Pontes de Miranda destaca também o caráter corporativo da Constituição de 1937, especialmente com a criação do Conselho de Economia Nacional e a acentuação de princípios advindos da Constituição de 1934, mas sem o problema do pluripartidarismo. Nesse sentido, tal centralização de poder teria apenas deslocado o presidencialismo dos seus compromissos estaduais e de uma democracia à maneira clássica para salvar o próprio presidencialismo e reestruturar a democracia. Ou seja, conclui o autor, "rigorosamente, a democracia pouco sofreu; o que sofreu foi o Poder Legislativo dos representantes do povo" (Pontes de Miranda, 1938: 181).

Araújo Castro, por sua vez, também afirma o caráter democrático da Constituição de 1937 e a definição de que "a democracia é a forma de governo em que o poder soberano pertence ao povo", sendo ela de tipo "direta ou absoluta quando o governo é exercido diretamente pelo povo". Porém, diz ele, esse sistema seria possível apenas nas pequenas cidades, sendo absolutamente impraticável nos Estados modernos. Além da impossibilidade material do seu funcionamento, esse regime não se justificaria também porque "nem todos os homens estão em condições de resolver os problemas do governo". De outro lado, "se o governo direto é impraticável, o sistema do referendum pode, contudo, ser praticado com vantagem. (...) Ora, o meio que se afigura mais simples para alcançar tal objetivo [a concordância entre a assembleia e a vontade do povo] é submeter, nos casos de dúvida, o texto da lei à deliberação do eleitorado" (Castro, 1941: 44-45). A esse respeito, a fim de melhor esclarecer o seu conceito de democracia (e dos autores acima referidos), deve-se aqui definir o que o autor entende por povo e pela sua soberania. No primeiro caso, diz ele, "a palavra 'povo' comporta duas significações bem distintas: uma geral, para designar todos os indivíduos que vivem dentro do território da nação e que a ela se acham vinculados pela raça, pelos costumes e pelos interesses comuns, sem distinção de sexo ou de idade"; e outra, de caráter especial, que se refere "somente a limitada classe de cidadãos a quem a constituição confere o direito de sufrágio e a prerrogativa de participar da gestão dos negócios públicos" (Castro, 1941: 38). Já no caso da soberania do povo, diz o autor, 
"tem-se em vista, em geral, o povo na primeira acepção, isto é, a nação", pois, usualmente, as palavras povo e nação são sinônimas: "assim também soberania do povo e soberania nacional são geralmente equivalentes. Quase todas as modernas constituições referem-se a soberania do povo ou soberania nacional" (Castro, 1941: 38-39).

Essas mesmas concepções seriam ainda partilhadas por juristas como Antônio Souto Castagnino e Antônio Figueira de Almeida, segundo os quais o caráter forte do regime não alteraria sua forma democrática, apenas criando uma nova estrutura legal de manifestação da opinião e de representação do povo. Para o primeiro, a Constituiçã̃o de 1937 não alterou o que seria substancial nos sistemas de opinião: "manteve a forma democrática, o processo representativo e a autonomia dos Estados, dentro das linhas tradicionais da federação orgânica" (Castagnino, 1938: 21). Em termos mais específicos, o segundo diria que "o voto universal tem o vício de permitir que os inferiores escolham os superiores. 0 voto indireto, sendo voto mais qualificado, cria para os eleitores a obrigação de selecionar os que vão ser votados" (Almeida, 1940: 45). Assim, em sintonia com Pontes de Miranda, Antônio Figueira de Almeida diz que a Constituição de 1937 teria mantido o princípio da representação de classes advindo da Carta de 1934, mas, dessa vez, orientado "do melhor modo, pois mantém as classes afastadas do jogo político e as circunscreve no seu campo próprio de ação construtora" (Almeida, 1940: 52). A seguir, contudo, referindo-se à livre manifestação do pensamento e da opinião, apanágio da democracia, o autor diz que esta liberdade "não pode ser utilizada arbitrariamente, de modo a promover desordem e provocar lutas entre os cidadãos", cabendo à autoridade "o dever de exercer censura prévia, e até de proibir, quando necessária, a difusão, representação e circulação do jornal, da peça teatral e do filme cinematográfico, ou da transmissão pelo rádio" (Almeida, 1940: 100). A arbitrariedade, nesse caso, não estaria na repressão do Estado, feita em nome da ordem e do interesse coletivo, mas na livre manifestação da opinião ou de interesses privados dos indivíduos. Em outros termos, portanto, pode-se dizer que a opinião desses juristas reitera a máxima acima citada de Francisco Campos de que o Estado brasileiro, sendo democrático, é também autoritário.

O mesmo se pode dizer quanto ao pensamento de Augusto Estellita Lins, que, de um lado, ressalva os excessos da democracia, mas, de outro, destaca o seu caráter dúctil. Em sua opinião, a democracia teria assumido nos tempos atuais um sentido grupalista, não devendo se limitar aos meios, como a representação partidária e o voto, mas se constituir numa democracia de meios para a consecução de fins, como a integração social do cidadão. Sua concepção de democracia grupalista, ainda que o autor não se estenda na definição do seu conceito e características, nos remete aos termos acima definidos por Oliveira Viana e 
Francisco Campos de uma Democracia Corporativa, baseada na organização das classes produtivas e sua incorporação ao Estado. Sobre os plebiscitos, principal instrumento democrático previsto na Constituição, o autor identifica na Carta de 1937 três diferentes tipos ou casos por ela previstos. No primeiro caso, há o "plebiscito constituinte para a consagração do novo Estado, o qual se realizará quando e como o Presidente da República decretar", e o "plebiscito constituinte de evolução normal no Estado", ambos de acordo, respectivamente, com os artigos 187 e 174 da Constituição. No segundo caso, há o "plebiscito legislativo de ratificação e aprovação da aprovação do Parlamento Nacional à incorporação, subdivisão, desmembramento e anexação de Estados", e o plebiscito legislativo de "ratificação do decreto presidencial sobre poderes de legislação do Conselho de Economia Nacional", de acordo, respectivamente, com os artigos 5o e 63 da Constituição. No terceiro caso, há o "plebiscito jurídico-eleitoral ou de recurso, posterior à cessação dos motivos do Estado de Emergência e resultante da desaprovação das respectivas medidas, a arbítrio do Presidente da República", regulado pelo art. 167 da Constituição. Quanto à natureza desses plebiscitos, se de governo direto ou indireto, Augusto Estellita Lins diz que "o plebiscito nacional do art. 187 da Constituição é o exercício direto do poder, enquanto os demais plebiscitos de que trata a constituição são atos de governo semidireto, no qual compartilham, já constitucionalmente, o órgão governamental e o povo" (Lins, 1938: 67-68).

Dito isso, deve-se a seguir citar alguns breves exemplos de como a Constituição de 1937, nos seus próprios termos, define as questões do plebiscito e da organização das corporações, apontados de modo consensual pelos intelectuais acima citados como seus fundamentos democráticos.

Quanto ao plebiscito, deve-se observar que o recurso à livre e direta manifestação do povo é citado em quatro dos seus 187 artigos - 50, 167, 174 e 187 - mas sempre por iniciativa e como ato de vontade do Presidente da República, nunca como sua obrigação legal ou forma de imposição de limites ao seu poder. No primeiro desses artigos, por exemplo, que trata da incorporação, subdivisão ou desmembramento dos Estados e de sua aprovação pelas Assembleias Legislativas e pelo Parlamento Nacional, seu parágrafo único estabelece que a resolução do Parlamento "poderá ser submetida pelo Presidente da República ao plebiscito das populações interessadas" (Constituição de 1937, art. 5, parágrafo único). No seu art. 63, a Constituição diz ser possível atribuir poderes legislativos ao Conselho da Economia Nacional nas matérias de sua competência, desde que "mediante plebiscito a regular-se em lei". Em seu parágrafo único, porém, fica estabelecido que "a iniciativa do plebiscito caberá ao Presidente da República, que especificará no decreto respectivo as condições em que e as matérias sobre as quais poderá o Conselho da Economia Nacional exercer poderes de 
legislação" (Constituição de 1937, art. 63, parágrafo único). Na prática, portanto, pode-se dizer que o seu parágrafo único anula o sentido do caput do art. 63, atribuindo diretamente ao Presidente da República não apenas a iniciativa de convocar o plebiscito, de acordo com a sua vontade e conveniência, mas também de especificar em decreto em que condições e sobre que matérias este Conselho poderá legislar. No caso do art. 174, sobre os poderes do Presidente da República e da Câmara dos Deputados para emendar, modificar ou reformular a própria Constituição de 1937, seu § 4ํe estabelece que, em caso de divergência entre eles sobre a aprovação de algum projeto, o Presidente poderá submetê-lo a plebiscito nacional, devendo este ocorrer "noventa dias depois de publicada a resolução presidencial. 0 projeto só se transformará em lei constitucional se Ihe for favorável o plebiscito" (Constituição de 1937, art. 174, § 4º). Já o plebiscito do art. 187, embora previsto apenas no último artigo da Constituição, em suas Disposições Transitórias e Finais, deveria ser o primeiro e mais importante a ser realizado, regulado também "em decreto do Presidente da República", justamente por se tratar do plebiscito que instituiria a própria constituição, daí seu caráter de plebiscito constituinte, como bem definiu Augusto Estellita Lins.

Já em relação ao seu sentido corporativo, deve-se aqui destacar o disposto no art. 38 da Constituição, segundo o qual "o Poder Legislativo é exercido pelo Parlamento Nacional, com a colaboração do Conselho da Economia Nacional e do Presidente da República (...)", além dos seus artigos 57 a 63 (Do Conselho da Economia Nacional) e 135 a 140 (Da Ordem Econômica), que vão regular a organização e funcionamento da nova democracia corporativa preconizada por Oliveira Viana e Francisco Campos e a incorporação das associações profissionais às estruturas de governo. 0 art. 57, por exemplo, diz que o Conselho da Economia Nacional será constituído por "representantes dos vários ramos da produção nacional, designados (...) pelas associações profissionais ou sindicatos reconhecidos em lei, garantida a igualdade de representação entre empregados e empregadores". Em seu parágrafo único, este mesmo artigo determina a divisão do Conselho da Economia Nacional em cinco seções: da indústria e do artesanato; da agricultura; do comércio; dos transportes; do crédito (Constituição de 1937, art. 57, parágrafo único). Já em seu art. 61, a Constituição diz serem atribuições desse Conselho, dentre outras, "a) promover a organização corporativa da economia nacional" e "c) editar normas reguladoras dos contratos coletivos de trabalho entre os sindicatos da mesma categoria de produção ou entre associações representativas de duas ou mais categorias" (Constituição de 1937, art. 61, letras 'a' e 'c'). Nesse sentido, cabe ainda destacar o que estabelecem os seus artigos 136, que define o trabalho como "um dever social"; 137, sobre a legislação do trabalho e os contratos coletivos; 138, sobre as associações profissionais ou sindicais; 139, que institui a Justiça do Trabalho; e 140, que 
determina que "a economia da produção será organizada em corporações e estas, como entidades representativas das forças do trabalho nacional, colocadas sob a assistência e proteção do Estado, são órgãos deste e exercem funções delegadas de poder público" (Constituição de 1937, art. 140).

Ao longo de todo o regime, porém, nenhum desses plebiscitos jamais foi convocado pelo Presidente da República, sempre se valendo das já citadas prerrogativas do seu poder pessoal que a própria Constituição havia Ihe conferido. 0 mesmo se pode dizer em relação ao seu caráter corporativo, deixado à legislação ordinária e jamais regulado pelo governo, apesar da criação do Conselho de Economia Nacional, como bem observou Pontes de Miranda (1938: 25).

Face ao exposto, pode-se concluir que a Constituição de 1937 não apenas se constituiu numa norma de fato, cuja existência estaria limitada à força que a mantém, como bem diziam os professores da Faculdade Nacional de Direito do Rio de Janeiro, mas também num importante momento de institucionalização do regime, daí o grande esforço dos seus intelectuais e juristas para tentar justificar e legitimar jurídica e politicamente os seus termos como os de uma nova democracia corporativa. De forma paradoxal, contudo, a Constituição de 1937 reconheceu no Presidente a autoridade suprema do Estado e o colocou acima dela própria, ou seja, ela se constituiu verdadeiramente numa não-Constituição, não emanada de um poder constituinte nem submetida ao plebiscito previsto em seu art. 187.

\section{Notas}

1 Parecer publicado no jornal Correio da Manhã no dia 3 de março de 1945. Texto integral também disponível em Porto (2001).

2 Para maiores detalhes a esse respeito, ver Pontes de Miranda (1938).

3 Os artigos citados e analisados pelo autor são os seguintes: 50, 9o 11, 12, 18, 19, 30, 38, 39, 50, 56, 62, $63,64,65,66,67,69,72,73,74,75,76,77,78,84,86,87,89,96,98,99,114,116,161,162,163,166$, $167,168,169,170,171,173,174,175,176,178,180,187$.

4 A discussão mais sistemática sobre a organização das classes e o desenvolvimento dos Conselhos Técnicos aparece pela primeira vez na obra de Oliveira Viana em 1930, com a publicação de Problemas de Política Objetiva.

\section{REFERÊNCIAS BIBLIOGRÁFICAS}

ABREU, Luciano Aronne de. Autoritarismo político no Brasil: intelectuais e imprensa. In: e SILVEIRA, Helder Gordim da. De Vargas aos Militares. Porto Alegre: EDIPUCRS, 2014. 
ALMEIDA, Antonio Figueira de. A Constituição de dez de novembro: explicada ao povo. Rio de Janeiro: Imprensa Nacional, 1940.

BERFORD, Álvaro Bittencourt. O Estado Nacional e a Constituição de novembro de 1937. Rio de Janeiro: Z. Valverde, 1944.

CAMARGO, Aspásia. O golpe silencioso: as origens da República Corporativa. Rio de Janeiro: Rio Fundo Ed., 1989.

CAMPOS, Francisco. O Estado Novo e suas diretrizes. Rio de Janeiro: Imprensa Nacional, 1937.

1938.

Os problemas do Brasil e as grandes soluções do novo regime. Rio de Janeiro: Imprensa Nacional,

O Estado Nacional. Rio de Janeiro: José Olympio, 1940.

CARONE, Edgar. O Estado Novo. São Paulo: Difel, 1977.

CASTAGNINO, Antonio Souto. A nova constituição brasileira: promulgada aos 10 de novembro de 1937. Rio de Janeiro: A. Coelho Branco, 1938.

CASTRO, Araújo. A Constituição de 1937. Rio de Janeiro: Freitas Bastos, 1941.

CODATO, Adriano. A sociologia política brasileira em análise: quatro visões sobre o funcionamento administrativo do Estado Novo, Revista de Sociologia e Política, Curitiba, vol. 19, n. 40, outubro 2011, pp. 273-288.

GOMES, Ângela de Castro. A República, a história e o IHGB. Belo Horizonte: Argumentum, 2009.

LINS, Augusto E. Estellita. A nova Constituição dos Estados Unidos do Brasil. Rio de Janeiro: J. Konfino, 1938.

MARQUES, Raphal Peixoto de Paula. Estado de exceção e mudança (in)constitucional no Brasil (1935-1937), Revista História Constitucional, n. 14, 2013, pp. 353-386.

PÉCAUT, Daniel. Os intelectuais e a política no Brasil: entre o povo e a nação. São Paulo: Ática, 1990.

PONTES DE MIRANDA, F. C. Comentários à Constituição Federal de 10 de novembro de 1937. Rio de Janeiro: Irmãos Pongetti, 1938.

PORTO, Walter Costa. 1937 - Coleção Constituições Brasileiras, v. 4. Brasília: Senado Federal, 2001.

SILVA, Fernanda Xavier. As Constituições da Era Vargas: uma abordagem à luz do pensamento autoritário dos anos 30, Política \& Sociedade (periódicos UFSC), vol. 9, no 17, outubro de 2010, pp. 259-288.

SILVA, Hélio. 1937: todos os golpes se parecem. Rio de Janeiro: Editora Civilização Brasileira, 1970.

SILVA, Paulo Sérgio da. A Constituição Brasileira de 10 de novembro de 1937: um retrato com luz e sombra. São Paulo: UNESP, 2008.

VIANA, Oliveira. Populações meridionais do Brasil: história, organização, psicologia. São Paulo: Monteiro Lobato, 1920.

A evolução do povo brasileiro. 2ª ed. São Paulo: Monteiro Lobato \& Co. Editores, 1923. 
Problemas da política objetiva. São Paulo: Companhia Editora Nacional, 1930.

. Problemas da política objetiva. 2ª ed. (aumentada). São Paulo: Companhia Editora Nacional, 1947. . Problemas de direito corporativo. Rio de Janeiro: José Olympio, 1938.

. O idealismo da Constituição. 2ª ed. São Paulo: Companhia Editora Nacional, 1939. . Problemas de direito sindical. Rio de Janeiro: Max Limonad, 1943. 